\title{
Utilitarian Value Impact of E-Tail over Retail on Youth in India
}

\author{
Saraju Prasad ${ }^{1, *}$ \\ ${ }^{1}$ Biju Patnaik Institute of IT and Management Studies, Patia, Bhubaneswar, Odisha, India \\ *Correspondence: Biju Patnaik Institute of IT and Management Studies, Patia, Bhubaneswar, \\ Odisha, PIN: 751023, India. Tel: 91-943-718-0018. E-mail: saraju_prasad@rediffmail.com
}

Received: November 2, 2017 Accepted: November 7, 2017 Published: November 15, 2017

doi: 10.5296/erm.v3i1.12175 URL: https://doi.org/10.5296/erm.v3i1.12175

\begin{abstract}
Consumers today have changed from static to dynamic as the change in environment, demands and market volatility affects the perception about retailing. In the meantime consumer buying process has changed from complex to simple which indirectly change buying from traditional stores to e-commerce. This is a conscious upgradation of consumers' status from physical market place to virtual market. Consumer willingness for online purchases has changed because of over accessibility to e-commerce. But customers are not so much inclined towards online purchases as lots of risk is associated with that. The research is mostly focused on the behavior of college students towards internet purchases. The variables considered for the study that influences the online purchases. A sample size of 300 comprising of graduate students, engineering students and other professional students has taken in judgment sampling procedure. The dataset collected through questionnaire are analyzed through various statistical tools. The outcome of the study revealed that more than half of the respondents prefer to buy online in an average of Rs.7, 500 per month. Factor analysis has conducted to verify the importance each variables in online purchase and by this four factors generated which are reasonable, influences, accessible and serviceable respectively which has considered by the youth during their online purchases and give greater importance to utilitarian value.
\end{abstract}

Keywords: E-tail, Workload, Factor, Eigen, Value 


\section{Introduction}

Globalization enhanced the market and has a tremendous impact on the growth of e-tail is one of a kind which has dominated the market in recent years. On internet it is related to a e-commerce site where a vendor or a seller sells his/her product and services directly to the customer and allows payment through credit card, debit card, cash on delivery and e-wallet. Electronic data interchange helps in providing information to e-tail which carries out a successful run of business unit. Majority of the customer now access to e-commerce sites as for their necessary and convenience shopping especially in the urban areas. There are plenty of alternative e-commerce websites available for varieties of products and services for different consumer demographics. As per the report the current overall internet penetration in India is approximately $31 \%$. Urban India has the estimated population of 444 million with 269 million $(60 \%)$ internet users. In rural India, as per the 2011 of population 906 million has only 163 million (17\%) internet users. There is a scope of internet companies to penetrate through a great potential market of size approximately 750 million users. The study also talked about $77 \%$ of urban users and $92 \%$ of rural users using mobile as the primary device for internet. As majority of the customers cannot afford the smartphones therefore different mobile phone companies have focused on to introduce low priced cellphones with internet facilities. More and more companies are interested to penetrate into this segment which has resulted with a stiff competition on the basis of retail pricing and technology of the device.

The usage of mobile phone differs among rural and urban populations. The urban population has given more emphasis to services such as e-mails, social networking and online shopping while rural population is giving more time to entertainment in the form of video and audio content by which internet consumption increased. Rural has more susceptible to cellphone than computers for using internets. Internet user in urban India has grown by $7 \%$ to 263 million for year-on-year period ended October 2016 which is expected to increase upto 275-285 million by June 2017 and for rural India till the end of October 2016 internet user has grown by 22\% which is expected in between to 157 million and is forecast to reach 170-180 million by June 2017. The number of smartphone user in India has grown to 300 million whereby the smartphone market grew by $18 \%$ compared to the global smartphone market $3 \%$ for year ended December 2016. This shows that India had surpassed the US to become the second largest smartphone market in the world.

E-commerce business growth has gone through an exponential growth by the increasing interest of the internet users to purchase online and by this an increasing number of registered customers on e-commerce websites and purchasing more products through mobile phones. India is passing through a phase of a growth and development in the e-commerce sector which has given great opportunities to retail sector and there is a transformation of customer access from brick and mortar to brick and click. Social network has played a vital role to promote e-commerce by this Facebook's second largest audience is in India after the US. In India there exists a form of 'digital divide' where the all benefits of internet has not gone to the rural areas. As per the new government approved project, broadband connectivity should reach the local and village level i.e. Gram Panchayats which is further likely to enhance the e-commerce in India (Sharma, 2015). Khan and Mahapatra (2009) pointed out that information technology 
played a vital role in quality improvement service provided by the business units. The applications of e-commerce have reached in all areas of business starting from customer service to design new products. It facilitates information technology based business processes like online marketing and advertising, order taking and customer service to reach and interact with customers in all the facet by which it can reduce cost in managing orders and interacting with a wide range of suppliers and trading partners. The e-commerce adds significant changes in overheads to the cost of products and services (Rastogi). Internet has intensified the commercial activities and has made it an extremely effective mode of exchanging information between businesses and customers (Rowley, 2001). Thompson (2005) stated that the extension of internet technology has huge potential by which it reduces the costs of product and service delivery and extends geographical boundaries to reduce the distances between buyers and sellers together. Agrawal, et al. (2012) explained that the advent of e-commerce has reduced the cost for accessing companies and do the day to day business transactions. The upswing of e-commerce is happened by the awareness of its potential benefits to create business value (Salnoske, 1997). Most of the companies, irrespective of size are participating in business through e-commerce to extract some benefit from it. This research paper is an attempt to examine key variables in e-tail from a business point of view like focusing on benefits, challenges and factors to lead the market.

\section{Hypothesis}

This research has gone through a situation where individual expense on e-tail is increasing day by day of the customers. This expense through e-tail is affected by the hedonic or utilitarian value of the product along with the websites. Hypothesis can be formulated to study the relationship of e-tail expenses with hedonic or utilitarian value of the products and websites. Hence the hypothesis is:

$\mathbf{H}_{0}=$ E-tail expenses of customers depend upon the utilitarian value of the products in websites

$\mathbf{H}_{1}=$ E-tail expenses of customers do not depend upon the utilitarian value of the products in websites

\section{Objectives}

A new model of convenient shopping has developed through e-commerce which has enhanced the productivity through the business efficiency, automation process, e-commerce in traditional market chain, expansion and retention of customer base, reduction of operational costs and acquisition of a niche market has made a new model of convenient shopping through e-tail. (Noble, et al., 2006; Rohm and Swaminathan, 2004; To, et al., 2007) identified that customers use carts in websites to store items prior to online purchase and this has shown the utilitarian as well as hedonic reasons for using online cart. The researchers do not have the knowledge still now the reasons for placing items in a virtual cart. This study has the objectives to know the profile of customers shopping through e-tail in the Indian market 
and shifting preferences of customers from retail to e-tail and the factors responsible for it.

\section{Research Methodology}

A theoretical framework was developed from the literature and it can be known that benefits, challenges and success factors are the key factors of e-commerce to make a business successful. A survey conducted through questionnaires based on the refined list with the sample size of three hundred were sent to the youths and explored the extent to which each of the identified factors were perceived by the customers. The survey sought to explore benefits and challenges of e-tail that inhibit its successful in e-commerce operation. The data was gathered from serving questionnaire to the respondents and the responses, which are ordinal, are presented on a Likert Scale. For attitude measurement of customers the Likert scale is used in business research (Sekaran, 1992) to allow respondents to give opinion with degrees of agreement or disagreement (Kerlinger, 1986). The survey has made with the help of a structured questionnaire to collect data about the behavior for online shoppers in Bhubaneswar (capital of Odisha i,e. an eastern state of India). Respondents were asked to rate the benefits, facilities and advantages of e-tail in their online operations and kind of difficulties encountered during the operation. The purpose is to explore young respondents' awareness and browse of different e-tail services and by this process developed the attitude. The attitudes of respondents' are observed through the questionnaire with questions having Likert scale (5-point scale). The data collected were measured through an ordinal scale and for analysis non-parametric statistical tests were used (Siegel, 1988). Non-parametric tests are described as statistical procedures that use in ordinal-scaled data (Zikmund, 1991; Kerlinger, 1986; Jordon, 1985). The collected data were analyzed by using SPSS (Statistical Package for the Social Science) to get the inferences and conclusion (Cramer, 1998).

\section{Literature Review}

Global giants in retail want to enter the untapped retail industry in India to get the new market of vast middle class which is a key attraction for them. India has over 5 million retail outlets in the country but relatively less number of organized retail outlets. The organized retail sector will grow much faster in the next five years as because of the changing lifestyles, burgeoning income and favorable demographic outline of Indian consumers. Mohanty and Panda (2008) stated that retail sector in India occupies predominant place in terms of socio-economic growth of the country and e-tail as a part of e-commerce has greater penetration than the retail. Shafqatajaz (2015) discussed that e-tailing account around $10 \%$ of the overall growth of e-commerce market in India. E-commerce growth in total was estimated through lots of research work on the internet usage (Teo, et al., 1999), entry to commercial websites (Gonzalez and Palacios, 2004), website design (Kim, et al., 2003) and effectiveness of website from the consumers' perspective (Bell and Tang, 1998) and pricing paid placements on search engine (Sen, et al., 2008), and bidding (Bernard and Simone, 2011). There is a growing trend of online advertising which has emerged in 1998 (Fain and Pedersen, 
2006) and rapidly it has become the core area of any business model of the major search engines (Jansen and Mullen, 2008) and it became the most rapidly growing segments of the online marketing (SEMPO Research 2009). Search engine is a simple user interface whose importance has grown rapidly and become a most necessity element to surf the web (Chang and $\mathrm{Wu}, 2011)$. Search Engine Marketing (SEM) is one form of internet marketing which promotes the ranking of websites in the search engine's search results page which can make a website available for more web users and indirectly increase website traffic (iProspect, 2008). Ho et al. (2011) discussed about the exploration of SEO technology adopted in internet marketing to enhance the customer visibility. Kesharwani and Tiwari (2011) studied that the e-vendors success and failure depended upon the quality of website. Melody and Robert (2001) explained that the internet can provide timely information to customers because of its ability for instant communication and its availability 24 hours a day, 7 days a week (Lane, 1996) which enhances the quality of website. Internet marketing offers more choices and flexibility to customers (Lamoureux, 1997) and at the same time reduces the company's burden on huge inventories, storage costs, utilities, space rental, etc. (Avery, 1997). Customers perceive internet marketing is same as direct marketing because companies are trying to shorten the supply chain through online marketing (Edwards et al., 1998) and by this they can able to reduce commission and operating costs. Ruckman (2012) highlighted that marketers are seeing the advantages of internet search as it became an increasingly important tool during the purchasing process.

Sujana (2008) examined that cultural dimensions of the consumers has great importance on internet shopping patterns. Mishra and Mathew (2013) explained the behaviour of online consumer in India affected by few attributes like internet usage, perceived risks, and website etc. Kumar and Verma (2014) observed the urban infrastructure was much better in terms of the level of education, income, needs of the people which has given a platform to enhance e-retailing. Besides user friendly or ease of use (Ha and Stoel, 2009), consumer attitudes, perceived congruity of e-tail websites (Wang et al., 2009), and website acceptable look (Poddar et al., 2009) are important variables for the acceptance of online shopping in any website. The e-commerce companies also understand the importance of both hedonic and utilitarian motivations for online shopping (Arnold and Reynolds, 2003; Bridges and Florsheim, 2008). The utilitarian and hedonic motives of consumers towards the use of the internet are mostly interpersonal utility, information seeking, convenience, and entertainment (Papacharissi and Rubin, 2000). Utilitarian factors are mostly comprise of functional benefits and sacrifices (Overby and Lee, 2006) and motivates for internet shopping (Noble et al., 2006; To et al., 2007) and it also includes the purchase intention of customers during the given online shopping session and financial incentives benefits like saving of money through online price promotions. The hedonic aspect associated with the fun and enjoyment derived by the customers during shopping (Babin et al., 1994). Motivations due to hedonic aspects of shopping through online are related to various types like shopping categories, shopping with adventure, gratification shopping, idea shopping, value shopping etc. Entertainment is one form of hedonic component which is utilized in online shopping (Luo, 2002; Wolfinbarger and Gilly, 2001) which indirectly reduce boredom, enhance the spend time and improve the experience enjoyment (Wolfinbarger and Gilly, 2001). It enhances the satisfaction, change 
attitude towards the website and encourage for more website use of customers (Luo, 2002). It also intensifies consumers' pleasure, aesthetic enjoyment, and emotional joy associated with hedonic shopping (McQuail, 1987). Previous enjoyable experiences in the online browsing process increase the intensity of pleasure, arousal and encourage consumers to hunt novel products from different websites and chase responsively towards promotional incentives (Menon and Kahn, 2002).

The hedonic aspects of online shopping are mostly stimulation and pleasure which enhance the marketing effectiveness prior to use any cart (Menon and Kahn, 2002). More number of customers often uses the website for entertainment purpose (Mathwick et al., 2001) and few consumers are getting pleasure by placing the items in cart. Now putting an item in the cart is not mean to obtain a product rather than an experiential activity (Wolfinbarger and Gilly, 2001). Value shopping means looking for discounts, sales, or searching for price promotions on online purchases as understood mostly by consumers (Arnold and Reynolds, 2003). High monetary incentives encourages consumers to experience cost savings and achieve a higher level of economic control which will create a significant positive correlations with internet use (Charney and Greenberg, 2001; Flanagin and Metzger, 2001; Wolin and Korgaonkar, 2003). Usually consumers are keeping items in the cart to take advantage of retail offers at different timing which lowers the overall purchase cost, such as sales, price promotions, and free shipping. Online price promotions on several items provide an incentive for consumers to place different items in their cart which indirectly enhance the use of shopping cart. Many customers in internet expect price promotions offers from e-tailers which will be lower prices than offline retailers (Maxwell and Maxwell, 2001) but for the extra charges due to shipping and handling very often discourage shoppers from purchasing (Lueker, 2003; Magill, 2005). Therefore another most popular aspect of online price-related promotions is providing free shipping or free return in items. Besides that online price promotion schemes give more pleasurable web shopping experience (Menon and Kahn, 2002). These experiential online shoppers view the cart as a convenient way to organize items of interest and enjoy the active uses by clicking and placing an item in the cart. Sometimes consumer may use the cart for a purposeful ongoing search of items which fulfill his/her need (Bloch et al., 1986). The motivation behind the online shopping is the ability of consumers to search easily (Punjand and Moore, 2009).

\section{Analysis and Discussion}

This article research explores to the extent to which consumers use the online shopping sites and searching information about the different categories products for a potential future purchase trough e-tail than retail. It has not only given the information about the buying behavior of the customers through e-tail but has also analyzed the consumer utility value for the e-tail over retail. A thorough demographic study with relation to the types of shopping cart use across different products and product categories has analyzed by comparing the utilitarian and hedonic value of products and services. 
6.1 Demographic Profile

The demographic profile of the respondents shows that out of 300 respondents 153 males and 147 females and 77.3 percentage are below 25 and 22.7 percentage are from 25 to 30 years of age (Table 1 in annexure). Out of the total respondents 58.33 percentage of customer have switched over to online shopping and 41.67 percent of customer still have not completely switched over to online shopping and still prefer to buy from the physical store near by their locality (Table 2 in annexure). All respondents use their internet personally to buy products from online (Table 3 in annexure) and out of which 36 percent of customer have a once a month purchase from online sites and 28 percent of customer purchase once in a week or above from the online sites (Table 4 in annexure). Out of the total respondents 52 percent of customer buy product ranging from Rs.5, 000 - Rs.10, 000 and 2 percent of customer buy product for Rs.15,000 and above per month (Table 5 in annexure).

Table 1. Demographic Profile of Respondents

\begin{tabular}{lcc}
\hline Demographic Features & Number of Respondent & Percentage in Total Sample \\
\hline Gender & 153 & \\
Male & 147 & 51.00 \\
Female & & 49.00 \\
Age & 102 & \\
< 20 years & 130 & 34.0 \\
$\mathbf{2 0}-\mathbf{2 5}$ years & 68 & 43.33 \\
$\mathbf{2 5}-\mathbf{3 0}$ years & & 22.67 \\
Student Category & 100 & \\
Graduate Students & 87 & 33.33 \\
Engineer Student & 113 & 29.00 \\
Management Students & & 37.67 \\
Family Size & 216 & \\
$\mathbf{2}$ parents $\mathbf{1}$ child \& & & 72.00 \\
$\mathbf{2}$ parents $\mathbf{2}$ child & 84 & 28.00 \\
$\mathbf{2}$ parents 3 child \& & & \\
$\mathbf{2}$ parents 4 child & 51 & 17.00 \\
Income of Father & 192 & 64.00 \\
Rs10,000 - Rs50,000 & 57 & \\
Rs50,000 - Rs1,00,000 & & \\
Rs1,00,000 and above & 5.00 \\
\hline
\end{tabular}


Table 2. Percentages of Respondents Do Online Purchase

\begin{tabular}{lrr}
\hline Reduction in demand in traditional shopping & No. of Respondent & Percentage \\
\hline Switching to online & 175 & 58.33 \\
Not completely switch over to online & 125 & 41.67 \\
Total & 300 & 100 \\
\hline
\end{tabular}

Table 3. Percentages of respondents use Internet

\begin{tabular}{lrrr}
\hline Internet Use & & No. of Respondent & \multicolumn{2}{c}{ Percentage } \\
\hline & Yes & 300 & 100 \\
& No & 0 & 0 \\
Total & & 300 & 100 \\
\hline
\end{tabular}

Table 4. Percentages of respondents do Internet Shopping

\begin{tabular}{lrr}
\hline No. of times purchased & No. of Respondent & Percentage \\
\hline More than twice in a week & 21 & 7.00 \\
Average once in a week & 84 & 28.00 \\
Average once in a fortnight & 48 & 16.00 \\
Average once in a month & 108 & 36.00 \\
Occasionally & 39 & 13.00 \\
Total & 300 & 100 \\
\hline
\end{tabular}

Table 5. Average Spending of Respondents Through E-tail per Month

\begin{tabular}{lrrr}
\hline Spending & No. of Respondent & \multicolumn{2}{c}{ Percentage } \\
\hline Less than Rs.1,000 & 27 & 9.00 \\
Rs.1,000-Rs.5,000 & 81 & 27.00 \\
Rs.5,000-Rs.10,000 & 156 & 52.00 \\
Rs.10,000-Rs.15,000 & 30 & 10.00 \\
Rs.15,000+ & 6 & 2.00 \\
Total & 300 & 100 \\
\hline
\end{tabular}




\section{NI Macrothink}

\subsection{Analysis}

This Table 6 in annexure provides the $R$ and $R^{2}$ values where the $R$ value represents the simple correlation and is 0.957 (the "R" Column), which signifies a high degree of correlation among the 18 statements and gives validity to conduct factor analysis and the $\mathrm{R}^{2}$ value is 0.916 signifies the extent of total variation in e-tail expenses explained by the eighteen independent variable related to hedonic and utilitarian value of products and websites. The eighteen statements considered for the behavioral studies can be able to explain $91.6 \%$ of the decision which is very large i,e. and the increase in expenses in e-tail is directly affected by the hedonic and utilitarian values of the products and websites. The ANOVA table explains the extent of the regression equation fits the data (i.e., able to predict the dependent variable).

Table 6. R, R Square and Adjusted R Square Values for Validity

\begin{tabular}{|c|c|c|c|c|c|c|c|c|c|c|}
\hline \multicolumn{11}{|c|}{ Model Summary } \\
\hline \multirow[t]{2}{*}{ Model } & \multirow[t]{2}{*}{$\mathrm{R}$} & \multirow[t]{2}{*}{ R Square } & \multirow{2}{*}{$\begin{array}{l}\text { Adjusted R } \\
\text { Square }\end{array}$} & \multirow{2}{*}{$\begin{array}{l}\text { Std. Error of } \\
\text { the Estimate }\end{array}$} & \multicolumn{5}{|c|}{ Change Statistics } & \multirow{2}{*}{$\begin{array}{c}\text { Durbin-W } \\
\text { atson }\end{array}$} \\
\hline & & & & & $\begin{array}{l}\text { R Square } \\
\text { Change }\end{array}$ & F Change & df1 & $\mathrm{df} 2$ & $\begin{array}{l}\text { Sig. F } \\
\text { Change }\end{array}$ & \\
\hline 1 & $.957^{\mathrm{a}}$ & .916 & .911 & .464 & .916 & 171.328 & 18 & 283 & .000 & 2.158 \\
\hline
\end{tabular}

The Table 7 in annexure shows the output of the ANOVA analysis shows that the significance value is 0.00 (i.e., $p=.000$ ) which is below 0.05 and is statistically significant. The Table 8 in annexure shows 18 predictors out of which four are not significant and ten are statistically significant as $p<=0.5$. Out of ten statistically significant statements four statements coefficient are negative which would indicate that hedonic value (warranties offered in e-tail sites (s7), hassle free order placing(s11) and advertisement induced you to buy (s14), reviews from customers (s18)) has negative impact on decision for expending more on e-commerce and six statements coefficients are positive which indicate that utilitarian value (availability of wide variety products (s3), very quick delivery (s4), good packaging (s8), products are as per specifications (s10), gift inspired for product (s12), detail specifications available (s17)) of products or websites has highest impact to capture the attention and expend more on internet purchases. Hence the null hypothesis is accepted and explains positive relationship of e-tail expenses with the utilitarian value of the products i,e.

$\mathbf{H}_{\mathbf{0}}=$ E-tail expenses of customers depend upon the utilitarian value of the products in websites

That means majority of the customers e-tail expenses are increasing because of they give more importance to the utilitarian value of the product along with the websites they select to purchase. 
Table 7. ANOVA table for F-Test Significance

\begin{tabular}{llrrrrr}
\hline \multicolumn{7}{c}{ ANOVA $^{\mathbf{a}}$} \\
\multicolumn{1}{l}{ Model } & Sum of Squares & df & Mean Square & \multicolumn{1}{c}{ F } & \multicolumn{1}{c}{ Sig. } \\
\hline 1 & Regression & 664.455 & 18 & 36.914 & 171.328 & $.000^{\mathrm{b}}$ \\
& Residual & 60.975 & 283 & .215 & & \\
& Total & 725.430 & 301 & & & \\
\hline
\end{tabular}

a. Dependent Variable: Extent of expenses on Internet purchase

b. Predictors: (Constant), S18, S9, S2, S11, S13, S7, S16, S1, S14, S12, S17, S8, S6, S15, S3, S10, S5, S4

Table 8. Regression Analysis for Relationship between E-tail Expenses with Variables

\begin{tabular}{|c|c|c|c|c|c|c|}
\hline & & & Coefficients $^{\mathrm{a}}$ & & & \\
\hline & & Unstandardized & Doefficients & Standardized & $\mathrm{t}$ & Sig. \\
\hline & & B & Std. Error & Beta & & \\
\hline & (Constant) & -.203 & .179 & & -1.137 & .257 \\
\hline & $\mathrm{S} 1$ & .001 & .061 & .001 & .020 & .984 \\
\hline & S2 & .035 & .024 & .030 & 1.481 & .140 \\
\hline & S3 & .362 & .061 & .359 & 5.983 & .000 \\
\hline & S4 & .373 & .073 & .388 & 5.092 & .000 \\
\hline & S5 & -.124 & .077 & -.117 & -1.614 & .108 \\
\hline & S6 & -.080 & .047 & -.075 & -1.709 & .089 \\
\hline & S7 & -.239 & .039 & -.259 & -6.086 & .000 \\
\hline & S8 & .488 & .044 & .479 & 11.132 & .000 \\
\hline 1 & S9 & .003 & .018 & .003 & .158 & .875 \\
\hline & S10 & .556 & .071 & .536 & 7.874 & .000 \\
\hline & S11 & -.060 & .025 & -.051 & -2.439 & .015 \\
\hline & $\mathrm{S} 12$ & .096 & .045 & .089 & 2.121 & .035 \\
\hline & $\mathrm{S} 13$ & -.037 & .036 & -.032 & -1.028 & .305 \\
\hline & S14 & -.325 & .077 & -.319 & -4.251 & .000 \\
\hline & S15 & .036 & .060 & .033 & .600 & .549 \\
\hline & S16 & .071 & .037 & .060 & 1.951 & .052 \\
\hline & S17 & .140 & .040 & .144 & 3.515 & .001 \\
\hline & S18 & -.247 & .046 & -.247 & -5.349 & .000 \\
\hline
\end{tabular}

a. Dependent Variable: Extent of expenses on Internet purchase 


\subsection{Customers' Shift Preference to E-Tail}

Attitude of Indian customers towards e-tailing especially the different shopping internet websites with reference to Bhubaneswar are studied through the factor analysis. The Cronbach's Alpha value for the eighteen statements is 0.904 which signifies the high reliability of the data for factor analysis (Table 9 in annexure). In Table 10 of annexure the sampling adequacy for the factor analysis came 0.842 (more than 0.5 ) and test of sphericity is significant as the value is lesser than 0.01 which shows the suitability of data for factor analysis. The total variance accounted for $73.96 \%$ is quite high and establishes the validity of the study (Table 11 in annexure). The Table 12 in annexure depicts the eighteen statements can able to generate four desired factors. The first factor "reasonable" identified with the seven statements. The second factor 'influential' explains the four statements. The third factor 'accessible' explains the four statements. The fourth factor 'serviceable' explains the three statements. Ranking made on the basis of the total factor score of each factors in Table 13 in annexure. The highest factor loads is 'reasonable', followed by 'influential', 'accessible' and 'serviceable' respectively.

Table 9. Reliability Test of the Variables with Cronbach's Alpha

\begin{tabular}{rr}
\hline \multicolumn{2}{c}{ Reliability Statistics } \\
\hline Cronbach's Alpha & N of Items \\
\hline .904 & 18 \\
\hline
\end{tabular}

Table 10. Sampling Adequacy Test for Factor

\begin{tabular}{llr}
\hline Kaiser-Meyer-Olkin Measure of Sampling Adequacy. & .842 \\
\hline \multirow{3}{*}{ Bartlett's Test of Sphericity } & Approx. Chi-Square & 3202.166 \\
& df & 153 \\
& Sig. & .000 \\
\hline
\end{tabular}

Table 11. Eigen Values for All the Variables

\begin{tabular}{|c|c|c|c|c|c|c|}
\hline \multicolumn{7}{|c|}{ Total Variance Explained } \\
\hline \multirow[t]{2}{*}{ Component } & \multicolumn{3}{|c|}{ Initial Eigenvalues } & \multicolumn{3}{|c|}{ Extraction Sums of Squared Loadings } \\
\hline & Total & $\%$ of Variance & Cumulative \% & Total & $\%$ of Variance & Cumulative \% \\
\hline S1 & 9.265 & 51.474 & 51.474 & 9.265 & 51.474 & 51.474 \\
\hline S2 & 1.653 & 9.186 & 60.659 & 1.653 & 9.186 & 60.659 \\
\hline S3 & 1.306 & 7.257 & 67.917 & 1.306 & 7.257 & 67.917 \\
\hline S4 & 1.088 & 6.046 & 73.963 & 1.088 & 6.046 & 73.963 \\
\hline S5 & .972 & 5.399 & 79.362 & & & \\
\hline
\end{tabular}




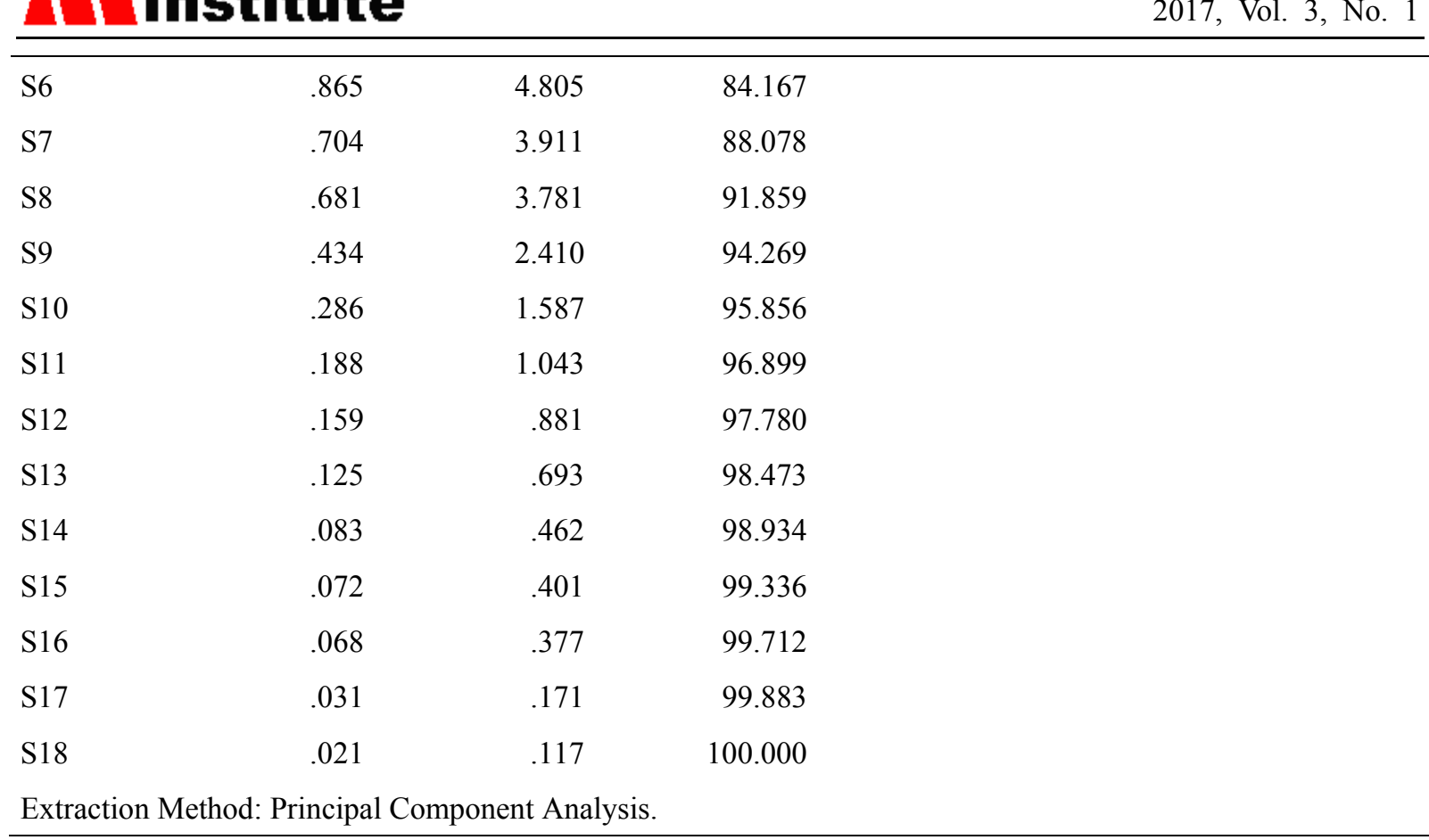

Table 12. Factors Considered by Respondents for Online Shopping

Price offered for products by e-tail sites are reasonable.(Statement-1)

(F1) Reasonable Quality offered by e-tail sites are up to the mark. (Statement-2)

A wide variety of products are available in e-tail sites. (Statement-3)

Warranties are offered by the e-tail sites. (Statement-7)

Placing order at e-tail sites is hassle free. (Statement-11)

Complete detail and specification of product is specified on e-tail sites. (Statement-17)

Better reviews from customers are specified on e-tail sites. (Statement-18)

Gift option inspired to purchase. (Statement-12)

(F2) Influential Buying from e-tail sites is influenced by word of mouth/friends. (Statement-13)

Advertisement by e-tail induced you to buy. (Statement-14)

Response from e-tail on services is quick. (Statement-16)

Products delivered at your door step are in good condition. (Statement-6)

(F3) Accessible Packaging of products is well maintained by e-tail sites. (Statement-8)

Products delivered are as per the specification specified at e-tail sites. (Statement-10)

Easy to track option makes task very easy. (Statement-15)

Delivery of items from e-tail sites is very quick. (Statement-4)

(F4) Serviceable After sale service by e-tail sellers is very good. (Statement-5)

Products are delivered by their own delivery system. (Statement-9) 
Table 13. Ranking of Factors on Score of Factor Loadings

\begin{tabular}{lcc}
\multicolumn{1}{c}{ Factors } & Factor Loadings & Rank \\
\hline F1(Reasonable) & 4.832 & 1 \\
F2(Influential) & 2.884 & 2 \\
F3(Accessible) & 2.671 & 3 \\
F4(Serviceable) & 2.092 & 4 \\
\hline
\end{tabular}

\section{Concluding Observation}

Online buying refers to the buying through websites or e-tails after browsing through the different e-commerce sites. Converting online shoppers to buyers is depending upon the hedonic or utilitarian value of the products in different websites through browsing, searching and gathering of information by considering various goods and services via electronic channels. For the online shopping the primary motivation factor is the inconvenience of physical movements from store to store will reduce through e-tail (Rohm and Swaminathan, 2004; Seiders, et al., 2000; Wolfinbarger and Gilly, 2001). E-tailers offer a pleasant and safe environment to engage shoppers in addition to continuous shopping convenience, (Bridges and Florsheim, 2008). There is no evidence of hedonic elements enhances online buying than the utilitarian elements (Bridges and Florsheim, 2008). The utilitarian elements are mostly considered by the consumers during the e-tail purchase like the first factor 'reasonable' contains the statements price offered for products, quality offered, wide variety of products, warranties offered, hassle free transactions, detail specification of product, and finally better reviews of customers respectively. Consumers may visit an e-tailer's site with the intent to make a purchase at that session on the basis of utilitarian value. The second factor 'influential' is mostly the hedonic aspects of the product in internet like gift option, word of mouth of friends, advertisement, quick perceived by customers. These hedonic elements have lesser influence than the utilitarian elements as observed through the factor analysis. The consumers who are shopping for fun, entertainment, reduces boredom are merely browsing from page to page, rather than actively adding items into the virtual shopping cart. Consumers are not always putting their products in virtual carts rather than they gather information about products and take decisions. It is fact that online shoppers mostly refrain from placing an item of interest into their virtual cart without upfront product or availability information. Therefore e-commerce websites provide detailed information to consumers prior to place an item of interest in their shopping cart.

\section{Limitations and Directions for Future Research}

This paper contributing important insights into the consumers who use online shopping carts, this research does have some limitations. The present data is a valuable contribution to hedonic and utilitarian value to the products which expected by most of the customers during purchase through online. Further research can be done in the area of experimental simulations 
which manipulate individual variables to capture the attention of customers. Furthermore the field of study can include examining interactivity, demographics, and emerging mobile commerce contexts. Interactivity can be studied by encounter in online shopping by human-message interactivity with a message sent by the e-tailer and by chatting with live customers in a human-human interaction (Ko, Chang-Hoan, and Roberts, 2005). Future studies should examine other populations to determine the generalizability of findings to different countries and contexts. Further research can be done for other theoretical bases to derive predictions of consumers' usability of online shopping cart. Researchers could study the extent to which the Theory of Reasoned Action (Fishbein and Ajzen, 1975) can help to explain behavioral intent and the subjective norms about the e-commerce websites.

\section{References}

Agarwala, R., Rastogi, S., \& Mehrotrac, A. (2009). Customers' perspectives regarding e-banking in an emerging economy. Journal of Retailing and Consumer Services, 16(5), 340- 351. https://doi.org/10.1016/j.jretconser.2009.03.002

Arnold M., \& Reynolds K. (2003). Hedonic shopping motivations. Journal of Retailing, 79(2), 77-95. https://doi.org/10.1016/S0022-4359(03)00007-1

Avery, S. (1997). Online tool removes costs from process. Purchasing, 123(6), 79-81.

Babin, BJ., Darden, WR., \& Griffin, M. (1994). Work and/or fun: measuring hedonic and utilitarian shopping value. Journal of Consumer Research, 20(4), 644-656. https://doi.org/10.1086/209376

Bell, H., \& Tang, N. K. H. (1998). The effectiveness of commercial Internet websites: a user's perspective. Internet Research: Electronic Networking Applications and Policy, 8(3), 219-228. https://doi.org/10.1108/10662249810217768

Bernard, J., \& Simone, S. (2011). Bidding on the buying funnel for sponsored search and keyword advertising. Journal of Electronic Commerce Research, 12(1), 1-18.

Bloch, PH., Sherrell, DL., \& Ridgway, NM. (1986). Consumer search: an extended framework. Journal of Consumer Research, 13(1), 119-126. https://doi.org/10.1086/209052

Bridges, E., \& Florsheim, R. (2008). Hedonic and utilitarian shopping goals: The online experience. Journal of Business Research, 61(4), 309-314. https://doi.org/10.1016/j.jbusres.2007.06.017

Chang, H.T., \& Wu, S. (2011). A Switching Proxy for Web Search Engines. Advanced in Information Sciences and Service Sciences. Advanced Institute of Convergence Information Technology, 3(5), 52. https://doi.org/10.4156/aiss.vol3.issue5.7

Charney, T., \& Greenberg, BS. (2001). Uses and gratifications of the Internet. In CA. Lin and D. Atkin (Eds.), Communication Technology and Society Audience Adoption and Uses. 
Cresskill, NJ: Hampton. pp. 353-378.

Cramer, D. (1998). Fundamental Statistics for Social Research, Step-by-step Calculation and Computer Techniques Using SPSS for Windows. Routledge, London.

Edwards, N., Handcock, S., \& Mullen, J. (1997). Electronic commerce: reality bytes. Supply Management, 3(8), 32-34.

Elliot, N. (2015). How Does Your Brand Stack Up On Facebook, Twitter, And Instagram?. September 15, 2015, Forrester Research Inc.

Fain, D.C., \& Pedersen, J.O. (2006). Sponsored Search: A Brief History. Bulletin of the American Society for Information Science and Technology, 32(2), 12-13. https://doi.org/10.1002/bult.1720320206

Fishbein, M., \& Ajzen, I. (1975). Belief, attitude, intention and behavior: An introduction to theory and research. Reading, MA: Addison-Wesle.

Flanagin, AJ., \& Metzger, MJ. (2001). Internet use in the contemporary media environment. Human Communication Research, 27(1), 153-181. https://doi.org/10.1093/hcr/27.1.153

Gonzalez, F.J.M., \& Palacios, T. M. B. (2004). Quantitative evaluation of commercial websites: an empirical study of Spanish firms. International Journal of Information Management, 24(4), 313-328.

Ha, S., \& Stoel, L. (2009). Consumer e-shopping acceptance: Antecedents in a technology acceptance model. Journal of Business Research, 62(6), 565-571. https://doi.org/10.1016/j.jbusres.2008.06.016

Ho, L.H., Lu, M.H., Lee, C.P., \& Peng, T.F. (2011). Exploration of Search Engine Optimization Technology Applied in, Internet Marketing. Advances in Information Sciences and Service Sciences, 3(7).

http://insightssuccess.in/understanding-e-commerce-in-india/

http://www.livemint.com/Industry/QWzIOYEsfQJknXhC3HiuVI/Number-of-Internet-users-i n-India-could-cross-450-million-by.html

Internet Live Stats (www.InternetLiveStats.com) Elaboration of data by International Telecommunication Union (ITU), United Nations Population Division, Internet \& Mobile Association of India (IAMAI), World Bank (2015).

IProspect, (2008). Information, available at http://www.iprospect.com/search-engine-marketinguniversity/, accessed during January 2013.

Jansen, B.J., \& Mullen, T. (2008). Sponsored search: An overview of the concept, history, and technology. International Journal of Electronic Business, 6(2), 114-131.

Jordon, C. (1985). Introduction to Business Economic Statistics. South western publishing Co; Cincinati. 
Kerlinger, F. (1986). Foundations of Behavioural Research, Harcourt. Brace Jovanovich College Publishers, Orlando.

Kesharwani, A., \& Tiwari, R. (2011). Exploration of Internet Banking Website Quality in India: A Webqual Approach. Great Lakes Herald, 5(1), 40-58.

Khan, M. S., \& Mahapatra, S. S. (2009). Service quality evaluation in internet banking: an empirical study in India. International Journal of Indian Culture and Business Management, 2(1), 30-46. https://doi.org/10.1504/IJICBM.2009.021596

Kim, S. E., Shaw, T., \& Schneider, H. (2003). Web site design benchmarking within industry groups. Internet Research, 13(1), 7-26. https://doi.org/10.1108/10662240310458341

Koa, H., Chang-Hoan, C., \& Roberts, H. (2005). Internet Uses and Gratifications: A Structural Equation Model of Interactive Advertising. Journal of Advertising, 34(2), 57-70. https://doi.org/10.1080/00913367.2005.10639191

Kumar S., \& Verma, S. S. (2014). E-Retailing in India: A Long Term Pan India Reality or a Short Term Urban Phenomenon? ZENITH International Journal of Business Economics and Management Research, 4(7), 95-104.

Lamoureux, T. (1997). IS goes shopping on the web. Computerworld, 31(46), 106.

Lane, A. (1996). Success in sight... or site?, Australian Accountant, 66(10), 22-25.

Lueker, T. (2003). Abandonment surveys help boost sales. Marketing News, 37(24), 16-21.

Luo, X. (2002). Uses and gratifications theory and e-consumer behaviors: A structural equation modeling study. Journal of Interactive Advertising, 2(2). https://doi.org/10.1080/15252019.2002.10722060

Magill, K. (2005). Building a better shopping cart. Multichannel Merchant, 1(8), 18-19.

Mathwick, C., Malhotra, N., \& Rigdon, E. (2001). Experiential value: conceptualization, measurement and application in the catalog and internet shopping environment. Journal of Retailing, 77(1), 39-56. https://doi.org/10.1016/S0022-4359(00)00045-2

Maxwell, S., \& Maxwell, N. (2001). Channel Reference Prices: The potentially damaging effects of Napster. Proceedings of the Fordham University Behavioral Pricing Conference, 32 .

McQuail, D. (1987). Mass communication theory: an introduction (2nd ed.). London, Sage.

Melody Y. K., \& Robert T. C. (2001). A framework for analyzing the potential benefits of internet marketing. Journal of Electronic Commerce Research, 2(4), 157-163.

Menon, S., \& Kahn, B. (2002). Cross-category effects of induced arousal and pleasure on the internet shopping experience. Journal of Retailing, 78(1), 31-40. https://doi.org/10.1016/S0022-4359(01)00064-1

Mishra, S., \& Mathew, P. (2013). Analyzing Perceived Risks and Website attributes in 
E-Retailing: A Study from India. Journal of Internet Banking and Commerce, 18(2), $1-14$.

Mohanty, A.K., \& Panda, J. (2008). Retailing in India: Challenges and Opportunities. The Orissa Journal of Commerce, 19(2), 69-79.

Noble, S.M., Griffith, D.A., \& Adjei, M.T. (2006). Drivers of local merchant loyalty: understanding the influence of gender and shopping motives. Journal of Retailing, 82(3), 177-188. https://doi.org/10.1016/j.jretai.2006.05.002

Overby, JW., \& Lee, EJ. (2006). The effects of utilitarian and hedonic online shopping value on consumer preference and intentions. Journal of Business Research, 59(10-11), 1160-1166. https://doi.org/10.1016/j.jbusres.2006.03.008

Papacharissi, Z., \& Rubin, A.M. (2000). Predictors of internet use. Journal of Broadcasting and Electronic Media, 44(2), 175-196. https://doi.org/10.1207/s15506878jobem4402_2

Poddar, A., Donthu, N., \& Wei, Y. (2009). Web site customer orientations, Web site quality, and purchase intentions: The role of web site personality. Journal of Business Research, 62(4), 441-450. https://doi.org/10.1016/j.jbusres.2008.01.036

Punjand, G., \& Moore, R. (2009). Information search and consideration set formation in a web-based store environment. Journal of Business Research, 62(6), 644-650. https://doi.org/10.1016/j.jbusres.2007.04.013

Rastogi, R. "Country Report on E-Commerce" (India, Ministry of Communications and Information Technology), Department of Information Technology, Office of the Controller of Certifying Authorities), pp. 133-146.

Rohm, AJ., \& Swaminathan, V. (2004). A typology of online shoppers based on shopping motivations. Journal of Business Research, 57(7), 748-57. https://doi.org/10.1016/S0148-2963(02)00351-X

Rowley, J. (2001). Remodeling marketing communications in an Internet environment. Internet Research, Electronic Networking: Applications and Policy, 11(3), 203-212. https://doi.org/10.1108/10662240110397017

Ruckman, R.R. (2012). Advantages of Internet Marketing. Retrieved from $\mathrm{http} / /$ www.imgrind.com/10-advantages-of-internet-marketing/10.

Salnoske, K. (1997). Building Trust in Electronic Commerce. Credit World, 85(6), 9-11.

Seiders, K., Berry, LL., \& Gresham, LG. (2000). Attention, retailers! How convenient is your convenience strategy? Sloan Management Review, 41(3), 79-89.

Sekaran, U. (1992). Research Methods for Business: a Skill Building Approach. Wiley, New York.

SEMPO Research, (2009). The State of Search Engine Marketing 2008 Survey of Advertisers and Agencies Search Engine Marketing Professional Organization, SEMPO, February, 
Search Engine Marketing Professional Organization, 2009.

Sen, R., Bandyopadhyay, S., Hess, J. D., \& Jaisingh, J. (2008). Pricing paid placements on search engine. Journal of Electronic Commerce Research, 9(1), 33-50.

Shafqatajaz, (2015). E-retailing in India: Issues and challenges. Excel International Journal of Multidisciplinary Management Studies, 5(1), 72-81.

Sharma, A. (2015, 25 ${ }^{\text {th }}$ June). "Digital India - Making villages Smart", 25 Jun 2015, ETTelecom.com, Times of India Group.

Siegel, S., \& Castellan, J. (1988). Nonparametric Statistics for the Behavioural Sciences. McGrawHill, Inc; New York.

Sujana A. (2008). Adoption of Internet Shopping: Cultural Considerations in India and Australia. Journal of Internet Banking and Commerce, 13(2), 1-17.

Teo, T., Lim, V., \& Lai, R. (1999). Intrinsic and Extrinsic motivation in Internet Usage. Omega, 27, 25-37. https://doi.org/10.1016/S0305-0483(98)00028-0

Thompson, S. H. T. (2005). Usage and effectiveness of online marketing tools among Business-to-Consumer", B2C, firms in Singapore. International Journal of Information Management, 25, 203-213. https://doi.org/10.1016/j.ijinfomgt.2004.12.007

To PL., Liao C., \& Lin TH. (2007). Shopping motivations on internet: a study based on utilitarian and hedonic value. Technovation, 27, 774-787. https://doi.org/10.1016/j.technovation.2007.01.001

Wang S., Beatty SE., \& Mothersbaugh DL. (2009). Congruity's role in website attitude formation. Journal of Business Research, 62(6), 609-615. https://doi.org/10.1016/j.jbusres.2008.05.020

Wolfinbarger, M., \& Gilly MC. (2001). Shopping online for freedom, control and fun. California Management Review, 43(2), 34-55. https://doi.org/10.2307/41166074

Wolin, LD., \& Korgaonkar, P. (2003). Web advertising: gender differences in beliefs, attitudes and behavior. Internet Research: Electronic Networking Applications and Policy, 13(5), 375-385. https://doi.org/10.1108/10662240310501658

Zikmund, W. (1991). Business Research Methods. The Dryden Press; Chicago.

\section{Copyright Disclaimer}

Copyright for this article is retained by the author(s), with first publication rights granted to the journal.

This is an open-access article distributed under the terms and conditions of the Creative Commons Attribution license (http://creativecommons.org/licenses/by/3.0/). 